\title{
THE MYTH OF "GOOD FAITH" IN COLLECTIVE BARGAINING
}

\author{
E. E. PALMER*
}

One of the basic assumptions of Canadian labour legislation is that the State's role is not to make collective agreements compulsory, but rather to require in all cases collective bargaining as a prerequisite to the use of the traditional economic weapons of industrial warfare. ${ }^{1}$ Put another way, it is the purpose of such legislation to require the parties to bargain with each other in the hope that out of this process agreement will result, thereby avoiding pernicious economic conflict. ${ }^{2}$ As Professor Wellington has stated, the assumption is that, "If a union and an employer are required to explain their respective positions, to listen to reasoned argument, to pursue the quest for agreement with sincerity, the chance for agreement without warfare will be enhanced." For this reason the burden of legislation relating to the settlement of industrial disputes in Canada has centered on methods of improving the chance of settlement rather than the laying down of specific content of agreements. The basic tool adopted to achieve this end has been compulsory conciliation. From the beginning of the century this policy of Mackenzie King ${ }^{4}$ has been the cornerstone of all Canadian legislation." The overwhelming stress placed on this mechanism however, has had the effect of obscuring another legal concept central to the process of negotiation: the requirement that parties "bargain in good faith." has had the effect of precluding the latter requirement. ${ }^{7}$

This imbalance is both curious and dangerous: curious because "bargaining in good faith" logically would seem to merit the initial attention of Government before third parties were involved, especially as we have the U.S. pattern before us stressing private bargaining and eschewing

- B.A., M.A., LL.B., LL.M., Associate Professor of Law, The University of Western Ontario.

1 See this point discussed in Bromke, The Labour Relations Board in Ontario: A Study of the Administrative Tribunal (1961).

2 This policy has been a cornerstone of all Canadian legislation since its formulator Mackenzie King, placed it as an article of faith in the original I.D.I. Act. See King, Industry and Humanity (1916); also Woods, Canadian Collctive Bargaining and Dispute Settlement Policy: An Appraisal (1955), 21 Can. Jo. Ec. \& Pol. Sci. 151.

3 Wellington, Freedom of Contract and the Collective Bargaining Agreement (1964), 112 U. Pa. L. Rev. 467, 471.

4 Ante, n. 2.

5 At present see the Industrial Relations and Disputes Investigation Act, R.S.C. 1952 c. 152, 11.2(1) (e), 14; The Alberta Labour Act, R.S.A. 1955, c.167, s.55(1) (b): The Labour Relations Act. R.S.B.C c.205 ss.2(1), 18: The Labour Relations Act, R.S.M. 1954, c.132, ss.2 (1) (e), 14; The Labour Relations Act, R.S.N. 1952, c.258, ss.2 (1) (e) 14; The Trade Union Act. R.S.N.S. 1954, c.295, ss.1 (e), 14; The Labour Relations Act, R.S.O. 1960, c.202, ss.12; The Industrial Relations Act, Stats. P.E.I. 1962, c.18, ss.1 (e), 17; The Labour Code, R.S.O. 1964, c.141, a41; and The Trade Ünion Act. R.S.S. (1953), c.259 8.2(1). [Hereinafter these acts will be cited by jurisdiction only, as: Can. s.2(1) ] Of these Alberta, Ontario, Quebec and Saskatchewan specifically use the term "good faith", others refer to every "reasonable effort" to reach agreement.

- It should be noted not all acts add the appendage of good faith to the requirement for bargaining, as is the case in Ontario: Ont., s.12. However, with or without the epithet, the tendency of courts and boards is to look at the concept in a similar light: $R e S$. $L$. Allen \& Co. (1936), 1 N.L.R.B. 714, 727.

7 The argument here runs that compulsory conciliation permits the parties to shuffle off responsibllity for reaching a settlement on to the board, or at least delay real bargaining until after concillation. See, e.g.. Woods, Labour Relations Law and Policy in Ontario (1958), 1 Can. Pub. Admin. no. 2) 1, 11-12. 
public intervention; ${ }^{8}$ and potentially dangerous because it is apparent that our faith in conciliation as a panacea for industrial strife has proved to a degree ill-founded, with many persons saying this process causes more unrest than it settles. ${ }^{\ominus}$ With this foundation of legislation crumbling, it must be decided which way new developments should move. Apart from modifications of the conciliation process three directions seem open: complete freedom in bargaining; measures moving toward the enforced arbitration of the contents of collective agreements; or greater emphasis on the conduct of bargaining. Initially, because of the Canadian tendency to ape the U.S., the latter path seems the more likely of the three. For this reason, and because it has been so little litigated in practice or examined theoretically, ${ }^{10}$ an attempt should be made to adumbrate the law in this area, its future, and its possible implications in the field of industrial relations.

I

Assuming that an Act requires bargaining "in good faith", the exact meaning of this latter term becomes of extreme importance. In practice, specific definitions have been less than satisfactory. There seems complete agreement on the part of judicial agencies entrusted with its administration that "good faith" relates to the procedure of collective bargaining rather than issues of agreement, ${ }^{11}$ the Boards pointing out, however, that this concept "was not intended to specify an exact procedure which must be followed by parties during the course of bargaining, but rather to ensure that a party, having given or received notice, will not neglect or refuse to meet with and enter into negotiations with the other party."12

"Good faith", however, does not stop at merely bringing the parties together; once together the quality of the talks takes on paramount importance. It is here that Boards usually lapse into generalities such as, "Bargaining in good faith must involve making every reasonable effort to make a collective agreement," with "reasonableness" left undefined. ${ }^{13}$ Again, it is common to sidestep this issue by saying that, in the cir-

8 The development of the American position is shown in many articles, the best of which are Cox, The Duty to Bargain in Good Faith (1958), 71 Harv. L. Rev 140-, and Smith, The Evolution of the "Duty to Bargain" Concept in American Law (1945), 39 Mich. L. Rev. 1065. Others to see are those quoted throughout this article, as well as Benetar,
The Duty to Bargain and the Right to Communication and McCulloch, The Consequences of the N.LR.B. Action on Good Faith Bargatning in Proc. N.Y.U. 17th Ann. Cont. Lab. 169, 415 (1964), Delong, Good Faith in Collective Bargaining (1959), 12 U. Fla. L. Rev. 378; Duvin, The Duty to Bargain: Law in Search of Policy (1964), 64 Colum. L. Rev. 248; Farmer, Good Faith Bargaining over Subcontracting (1963), 51 Geo. L.J. 558; Miller, The Enigma of $8.8(5)$ of the Wagner Act (1965), 18 Ind. Lab. Rel. Rev. 166; and Note
(1964), 18 Vand. L. Rev. 258.

- The most trenchant criticisms of this mechanism have been made by Professor Woods: see esp. ante, notes 2 and 7 . See also the views set out in Industrial Relations Centre, MCGill University, Rep. 7th Ann. Conf. (1955).

10 There are no Canadian articles on this topic and the paucity of these cases has been noted in Logan, State Intervention and Assistance in Collective Bargaining: The Canadian Experience, 1943-1954, 49-50, 62, (1956). For example, the Canada Labour Relations Board dealt with only six such cases between September 1, 1948, and March 31 , tions Board dealt with only six such cases between September 1, 1948, and March 31, fallure to bargain in good faith only beling made in one.

11 See this point made in Brown, Interpretation of Good Faith Bargaining (1961), West. Res. L. Rev. 612, 613, and Ward, The Mechanics of Collective Bargaining (1940), 53 Harv. L. Rev. 754.

12 Re Oliver Lumber Co., OLRB Mon. Rep. Aug. 63, at 280.

13 Per McRuer, C.J.H.C., quoted in Reg ex rel. Hodges v. Dom. Glass Co. (1964), 45 D.L.R. (2d) 109 (Ont. C.A.). A sample of the U.S. declaration is:

"True collective bargaining involves more than the holding of conferences and the exchange of pleasantries... While the law does not compel the partles to reach agreement, it does contemplate that both parties will approach the negotiations with open mind and will make a reasonable effort to reach a common ground of agreement." Re Connecticut Coke Co. (1934), N.L.B., pt. 2, 88, 89. 
cumstances of a particular case, the obligation to bargain exists without defining that obligation. Thus, Boards have held that the obligation to bargain exists after the handing down of a conciliation report ${ }^{14}$ or the failure to renew a collective agreement. ${ }^{15}$ It has also been held that this obligation continues after strike or lockout action has been taken by one side. ${ }^{16}$ The only difference in these cases is that as each of these new factors is introduced into the case, ${ }^{1 i}$ "the nature and extent of the bargaining in which the party is required by law to engage at that point may be quite different from what they were earlier." This presumably narrower obligation to bargain is again given no positive definition as:" "Each case will turn on its own peculiar facts and there is little profit in seeking to set out ... views on what must of necessity be a series of hypothetical situations," Ultimately, as is the case in the U.S. ${ }^{19}$ the parties will be permitted to reach an impasse at which time the obligation to bargain has completely withered." Since the concept of "good faith" bargaining was introduced into labour relations to prevent unions from being "talked to death,"21 it is for Boards to struggle with the exact meaning of "good faith" in individual cases Definitive statements of the phrase "bargaining in good faith" have been both difficult to formulate and impossible to apply; one of the probable reasons for this phenomenon is that the activity which the phrase represents is too complex and too changing to admit to a complete definition. ${ }^{22}$ Hence, its development has been, as is the usual manner in difficult legal situations, tentative and groping; the negative definition being preferred to the positive. Defining "bargaining in good faith" in this manner is justifiable and not novel. Of this approach, articulated in the United States by the famous labour lawyer, Judge Magruder, in NLRB v. Reed \& Prince Mfg. Co., ${ }^{23}$ Professor Cox has stated: ${ }^{24}$

"It avoids most of the difficulties inherent in earlier efforts to define good faith because it contains no suggestion that a negotiator must put reaching an agreement ahead of maintaining his position concerning substantive terms and conditions of employment. It also solves the chief problem to which the notion of good faith was originally directed, for it separates the employers who are seeking to talk a union to death from those who are merely stubborn negotiators exercising their full bargaining power."

This approach has validity for Canada and a review of the issues which have arisen in this area is required to evaluate the future of this concept. The field itself breaks down into three major areas: (i) problems centering around the extent to which subjective attitudes towards collective bargaining conflict with "good faith"; (ii) problems of when objective

14 E.g., Re New Method Laundry \& Dry Cleaners, CLS 76-533, CCH par. 16, 059 (Ont. 1957); appid. Re Deacon Bros. Sportswear, OLRB Mon. Rep. Dec. 62, at 357. InHotel \& Restaurant Employees \& Bartenders Int'l Union (1962), 36 D.L.R. (2d) 81 (Ont. S.C.), and (1963), 38 D.L.R. (2d) 675 (Ont. S.C.).

15 S.C.) and (1963), Print \& Wallpaper Co., OLRB Mon. Rep. Apr. 64, at 48.

16 E.E., Re Superior Box Co. (1961), CLS 76-719, CCH par. 16, 189 (Ontario)

17 Per.J. Finkelman, Chairman, in Re New Method Laundry \& Dry Cleaners, ante, n. 14.

$18 \mathrm{Ibid}$. [The] Act does not encourage a party to engage in fruitless marathon discussions at the expense of frank statement and support of his position." NLRB v. American Nat'l Ins. Co. (1952), 343 U.S. 395, 404

20 See Reg. v. Norfolk' General Hospital (1957), 119 C.C.C. 290 (Ont .Mas. Ct.); and Mitchell v. Chadwick, [1948] 2 D.L.R. 157 (Sask. C.A.). Cf. Finkleman J., in Re New Method Laundry, ante, n. 14: une existence of a barsaining imploser to accept the destroy the authority of the union to seek to persuade the employer to accept the position of the group as to the particular terms that should govern the emplosm the relationship isiten to this persuasion?

21 See Cox, The Duty to Bargain in Good Faith (1958), 71 Harv. L. Rev. 1401, $1412-13$.

22 See, on this point, Woods, ante, n. 7, at 3 .

23 205 F. 2d 131, 134 (1st Clr.); cert. denied (1953), 346 U.S. 887.

24 See Cox, ante, n. 21, at 1407. 
activity at the bargaining table itself does not constitute good faith; and (iii) the extent to which external pressures may be applied during bargaining.

(i) The first group of these cases stems, in part at least, from the fact that collective bargaining is a fairly new experience for Canadians and so there remain some employers who do not have a very sophisticated knowledge of its logical concomitants. These men have often taken positions consistent with the requirement to bargain in good faith as long as "good faith" is regarded as a subjective standard. This is shown in the many cases where Companys have refused to bargain with unions on the basis that they felt the union no longer had the support of the employees in the plant concerned, i.e., that the union no longer had membership of the majority of these men. The Boards have consistently rejected this position: after certification the union retains rights because of representation, not membership; but it was the objective act rather than the subjective attitude of the employer which formed the gravamen of the decision. ${ }^{25}$ Again difficulties have arisen where management has taken the position that it will refuse to bargain with unions' bargaining committees when their membership either lacks members from among its [the company's] employees or has members employed by competing firms. This, although understandable, has been held in the same way as the previous situations to be an unfair labour practice, the reasoning being either that the legislation in question authorizes this activity $^{26}$ or that the union has been given a free hand in the choice of representatives. ${ }^{27}$ Thus, although from a subjective point of view the employers involved were acting in good faith in that they felt they were complying with the spirit of the legislation, it was only the objective act that was held to be an unfair labour practice.

Parenthetically, it might be pointed out that up until 1964 this matter was avoided in at least one jurisdiction by legislation which required bargaining committees to be composed of employees of the employer and, if desired, officers or representatives of the trade union involved. ${ }^{28}$ Unfortunately, this approach has been dropped; ${ }^{20}$ thus all present legislation refers only to the meeting of the parties, i.e., the union and the company, hence, it would seem there is no case for a company to demand that its employees ${ }^{30}$ be present or that employees of its competitors be absent. ${ }^{32}$

Instances where companies have refused to bargain because of financial difficulties ${ }^{32}$ or because of other potential changes in the corporate set-up $^{33}$ are also illustrations of findings of breach of s. 12, nothwithstand-

25 See Re Bentley's Sporting Goods (1959), 2 CLS 76-629, CCH par. 16, 129 (Ont.); cf. Re Deacon Bros. Sportswear (1962), December Monthly Report 357. See also Army \& Navy Dept. Store v. Retail, Wholesale \& Dept. Store Union (1962), 35 D.L.R. (2d) 605 (Sask. C.A.) for a variant of this agreement which was equally unsuccessful.

20 E.g., Re Marshall-Wells Co. (1955), par. 16, 002 (Sask.); aff'd on cert. Marshall-Wells Co. v. Retail, Wholesale \& Dept. Store Union, Loc. 454 (1956), 2 D.L.R. (2d) 569 (Can. S.C.), aff'ng [1955] 4 D.L.R. 591 (Sask. C.A.).

27 U.S.W. of A., Loc. 2853 v. Welland Vale Mfg. Co., [1943] 3 D.L.R. 786 (Ont. Lab. Ct.); U.S.W. of A., Loc. 1005 v. Steel Co. of Can., [1944] 2 D.L.R. 583 (Ont. Lab. Ct.).

28 Ont., s. 13.

29 (Ont.) 1964, c. 53, s. 2.

30 See Re Twin City Laundry, OLRB Mon. Rep. Jan. 65, at 527.

31 See ante, n. 26, and Re Superior Box Co. (1961), 2 CLS 76-719, CCH par. 16, 189 (Ont.).

32 E.g., Re Peller Brewing Co. (1951), CCH par 17, 019 (Ont.).

33 E.g., Re H. J. Craddocle (1948), DLS 7-1387 (Ont.) [a potential sale of the company or its assets]. 
ing subjective good faith. The Boards in these cases have stated that such activity does not relieve the Company from its obligation "to meet with the [union], to bargain in good faith and to make every reasonable effort to make a collective agreement." ${ }_{34}$ It might be pointed out that the first of these objections-inability to pay-may become an issue during the course of bargaining itself rather than an excuse not to bargain and the question then arises whether the Board will require the Company to "attempt to substantiate its economic position by reasonable proof," as is done in the U.S.

Finally, there are a group of cases which center around situations where an employer has clearly shown strong distrust of unions and a desire to have no agreement with them. Here again the Boards have avoided holding that such actions per se amounted to proof of failure to bargain in good faith. As it has been stated:"se "The bare fact that a party makes hostile or emotional statements in the heat of bargaining or takes an adamant or intransigent position, may not of itself, or when considered in context with other statements and actions of the party, warrant the conclusion that the party was not bargaining in good faith or making every reasonable effort to effect a collective agreement."

(ii) "Good faith bargaining" has also received attention in cases where Canadian boards have made some effort to determine which issues should or should not be discussed in bargaining. Obviously, at one end of the spectrum doing nothing constitutes bad faith. ${ }^{37}$ The Boards have here taken the position that at the very least it is "the duty of the employer to advise his employees what terms he [is] willing to accept ...." On the other extreme, the Boards have ruled that making manifestly unreasonable demands constitutes bargaining in bad faith, ${ }^{39}$ as does an attempt to force agreement on an illegal clause. ${ }^{40}$ Thus, it is in the area of legal and reasonable clauses that problems arise. In the United States the NLRB has stated that parties must discuss any proper matter of collective bargaining, and a "foreclosure of discussion ... [of such] is a negation of the good faith bargaining required by the statute." 41 Undoubtedly, this accurately indicates the Canadian position. It should

34 Re Peller Brewing Co., ante, n. 32.

85 Re Truitt Mfg. Co. (1954), 110 N.L.R.B. 856; enforcement denied (1955), 224 F. 2d 869 (4th Cir.) ; rev'd (1956), 351 U.S. 149.

36 Re Trenton Memorial Hospital (1964), 64 CLLC par. 1243 (Ont.). See also Re Lawson Motors (1953), CCH par. 16, 015 (N.B.), where an employer said: "I have a copy of the Labour Relations Act here in my hand and there is no law that says we have to abide by unions." The Board Chairman, H. A. Hanson said: "In my opinion, the words attributed to Lawson indicates a strong distrust in unions and a desire to have no agreement with a union. This alone would not be sufficient to constitute an offence While the Act can compel an employer to bargain in good faith with the union, it cannot legislate cancerning his state of mind"

It should be noted in this respect that, semble, stupidity is not incompatible with bargaining in good faith: Reg. v. Norfolk General Hospital, ante, n. 20, at 291 .

87 See Re Radio Oil Refineries (1959), CLS 60-1017, CCH par. 16, 160 (Man.); and Re Superior Box Co., ante, n. 31.

38 Per H. A. Hanson. Board Chairman, in Re Lawson Motors, ante, n. 36. See also Brennan J. In NLRB v. Katz (1962), 369 U.S. 736: "The duty to bargain can . . . be violated without a fallure of subjective good faith; for there is no occasion to consider the issue of good faith if a party has refused even to negotiate in fact ... ".

so See, e.g., where a Company demanded a $\$ 500,000$ performance bond and a 25-year contract: Re Radio Oil Refineries, ante, n. 37.

to See Re T. Barbisen \& Sons, OLRB May Mon. Rep. May 60, at 80; Re McPherson Warehousing Co., OLRB Mon. Rep. Feb. 65, at 583; and Re Canada Bread Co. (1945) CCH par. 10, 430 (Ont.). Cf. Utah Co. v. I.U.O.E. (1959), 21 D.L.R. (2d) 166 (Sask C.A.). Quaere: can demands for legal clause ever be the basis for a claim of bad faith bargaining? See NLRB v. Borg Warner (1958), $356 \mathrm{U} . \mathrm{S}$. 342, and discussion on it in Fleming, The Obligation to Bargain in Good Faith (1961), 47 Va. L. Rev. 988, 996.

11 Re Andrew Jurgens Co. (1948), 76 NLRB 363, 366; enforcement granted (1949), 175 F. 2d 130 (9th Cir.). Discussed in Brown, ante, n. 11, at 618 et seq. 
also be pointed out that when new factors relevant to the bargaining of the parties occur, such as the recommendations of a board of conciliation, the parties must at least discuss these. A failure to do so constitutes a failure to bargain in good faith. ${ }^{12}$

One question remains unanswered in Canada: assuming that you are dealing with a reasonable and legal issue, how far are particular issues more important to the process, thereby necessitating a greater devotion of time and energy by the parties? In short, do issues which are necessary to establish a valid collective agreement have a significance in relation to good faith that others do not? In the U.S. this distinction has been made, ${ }^{43}$ but as yet Canadian jurisprudence does not seem to have risen to this level of sophistication.

(iii) A third problem with which Canadian Boards have grappled is that, assuming bargaining at the table is proceeding satisfactorily, to what extent is the use of economic power compatible with contemporaneous "good faith" bargaining. At first blush, one is tempted to accept the view that:"4

\begin{abstract}
"There is not the slightest inconsistency between genuine desire to come to an agreement and use of economic pressure to ge the kind of agreement one wants .... [N]o inference of failure to bargain in good faith could have been drawn from a total withhold of services, during negotiations, in order to put economic pressure on the employer to yield to the Union's demands. As a simple matter of fact ... no such inference can be drawn from a partial withholding of services at that time and for that purpose."
\end{abstract}

Upon more mature consideration, however, complete aceptance of this position is impossible; some limitations must be put on it.

It would seem clear that to be valid any economic pressure employed must be legal. Thus, strikes or picketing which are themselves illegal by statute or at common law would be incompatible with "good faith" bargaining. ${ }^{\text {s }}$ Secondly, specific legislation may make certain practices illegal during bargaining, such as unilateral changes in employment conditions by an employer. ${ }^{8}$ The knottier problems relates to the use of legal economic pressures. Perhaps the safe answer is to leave all such actions beyond the purview of regulation-a true laissez-faire position. ${ }^{47}$ It should be noted, however, that in the United States stress on "good faith" has moved the Boards into regulation of this area and it would seem inevitable that Canada will follow the same path. If this is so a rather clear tension has developed between the requirements of "good faith" on the one hand and freedom to resolve economic dispute by economic power on the other.

12 See Re New Method Laundry and Dry Cleaners, ante, n. 14.

48 See Fleming, ante, n. 40.

44 Personal Products case (1955), 227 F. 2d 409, 410 (D.C.Cir.); (1956), 352 U.S. 864. See also Ins. Agents Int'l Union v. NLRB (1960), 361 U.S. 477; Recent Decision: (1957), 41 Mara. L. Rev. 200; Comment: 71 Harv. L. Rev. 502.

15 Nippissing Hotel $v$. Hotel \& Restaurant Employees ... Int'l Union, ante, n. 14. See also the Personal Products case, ibid., when before the NLRB: (1954), 108 NLRB 743 .

16 E.g. Ont., 8. 59. In the U.S. a similar position has been reached; see Bowman, An Employer's Unilateral Action-An Unfair Labor Practice? (1956), 9 Vand. L. Rev. 487. For contrary views in Canada, see U.M.W. v. Dom. Coal Co. (1922), 63 D.I.R. 274 (N.S.S.C.), and Ferguson and Lawson v. Paterson S.S., [1950] 4 D.L.R.' 525 (Ont.).

17 E.g., The Ontario Board has held that a strike does not end the obligation of parties to bargain, although they indlcated there would be some difference in the obligation: Re Superior Box Co., ante, $\mathrm{n}$. 31 . The unexplained difference is probably that mentioned in Re New Method Laundry \& Dry Cleaners, ante, n. 14. This continuing oblisation to in Re New Method Laundry \& Dry Cleaners, ante, n. 14. This continuing obligation to bargain in the fact of strikes and lockouts has been a long-standing tenet of the labour
movement in Canada. See, e.8. Proc. N.W.L.B. Public Inquiry Into Labour Relations and Wage Conditions, 155-174, (1943). 


\section{II}

The foregoing description of developments in the concept of "good faith bargaining" would seem to indicate the inevitable development of certain problems, the first of which is the danger of introduction of rigidity into what should be a flexible system. ${ }^{48}$ This rigidity would seem to arise necessarily from the need to find criteria applicable by Boards. ${ }^{49}$ Thus, in the United States: ${ }^{50}$

"The experience of the Board and the courts over the years in judging the question of good faith has resulted in the establishment of certain indicia of bad faith. In some situations the acts or ommissions are only prima facie evidence; in others they are conclusive proof of bad faith. The tendency [s. 211] towards crystallization of the tests and away from balancing of intangible factors has become known as the 'per se' approach."

At present the Canadian Boards seem to be content to balance intangible factors, ${ }^{51}$ but with the increase in cases of this nature a per se test has attractions for the administrative mind. This rigidity will, if adopted have the effect of both diverting the attention of the negotiators from the central issue of hammering out an agreement and of setting standards for persons not really applicable to them.

A second area of concern centers around the extent to which the concept of "good faith" necessitates actually agreeing to something. In short, can you bargain in "good faith" and not reach agreement? The traditional position is that:"22 "The Act does not compel agreements between employers and employees .... . The theory of the Act is that free opportunity for negotiation with accredited representatives of employees is likely to promote industrial peace and may bring about the adjustments and agreements which the Act in itself does not attempt to compel ...." However, in the United States some authority is found for the proposition that when no agreement has been reached there has been bad faith because,"s "Agreement is possible wherever the will to agree is present." Thus, Professor Gregory has stated that: ${ }^{\text {st }}$

"The Board and the Supreme Court piously reiterate that section 8(a)(5) does not compel employers to agree to anything. But as a practiced matter, employers find it almost impossible to avoid committment to some extent over matters on which they are compelled to bargain under the statute. The difference between this and direct statutory command from Congress that certification matters must be included in contracts is only one of degree."

There is some indication that we in Canada may move in the same direction. In Re Lawson Motors, the Board said: ${ }^{53}$

"It is not sufficient for an employer when called upon to negotiate under the Act, to meet with the bargaining agent and discuss a collective agreement. He must do more. He must bargain in good faith. He must intend to conclude a collective agreement. Such intention can only be implied from words and conduct."

48 See this fear voiced in Duvin, The Duty to Bargain: Law in Search of Policy (1964), 64 Colum. L. Rev. 248, 285.

49 The inevitabllity of such an approach by administrative agencies is noted in Chamberlain, Collective Bargaining, $301-303$ (1st ed. 1951).

30 O'Nelll, The Good Faith Requirement in Collective Bargaining (1960), 21 Mont. $\mathrm{L}$. Rev. 202, 210-211. The "per se" doctrine was adopted in NLRB v. Katz (1962), 369 U.S. 736. See also Duvin, ante, $n$. 48 , at 277 .

$s 1$ See, e.g., Re New Method Laundry, ante. 14.

52 NLRB v. Jones \& Laughlin Steel Corp. (1936), 301 U.S. 1, 45. For Canada, see Re Toronto Graphis Arts Assn. (1949), DLS 7-2101, CCH per 17, 001 (Ont.) and Re Canada Press (1952), CCH par. 15, 004 (Ont. Cnty. C.A.).

63 Re S. Dresner \& Sons (1934), iN.L.B. 26, quoted in Smith, ante, n. 8. Opposite views such as that of Re Houde Engineering Corp. (1934), 1 NLRB (old) 35, are collected id., at 1081 .

54 Gregory, Labor and the Law 314 (2d ed. 1958).

sS Ante, n. 14, per H. A. Hanson. 
Does this mean that there must be compromise? If both Company and Union make different wage demands, both being within the realm of reason, must the Company come up and the union down? Assuming that union security provisions are common in an industry, is it unreasonable to agree to one? Extending the "good faith" concept along the lines set out above, the answers would seem inevitably to be in the affirmative. ${ }^{56}$ Thus, the inherent contradiction of injecting the concept of "good faith" into an area redolent with self-interest appears. As Professor Cox has noted," "The technique most conducive to reaching some agreement often excludes tactics most conducive to getting agreement on one's own terms." The undesirability of such developments is self-evident.

The efficacy of a development of the concept of "good faith bargaining" should also be measured against the sanctions provided for a negative finding on that topic. Two methods of enforcing the obligation to bargain have been used in Canada: mandatory orders by the Boards ${ }^{58}$ or consents to prosecute. ${ }^{50}$ In the past neither seem to have been satisfactory.

The initial problem with the latter and more usual approach lies in its quasi-criminal nature. In carrying out this function Boards technically are placed in a position equivalent to that of a magistrate at a preliminary hearing, i.e., their role is to decide if there is sufficient facts to establish a prima facie case. ${ }^{50}$ In fact, probably due to the severity of criminal sanctions in an inherently civil situaton, the Boards have gone a long way towards whittling down the rights to a prosecution in these cases by the use of discretionary rules used in ordinary cases ${ }^{61}$ as well as ones developed specifically for "bargaining in good faith" cases. Thus, consents have been refused by application of a "clean hands" doctrine, ${ }^{62}$ by saying that the application was untimely because no real attempt to bargain had yet been made ${ }^{68}$ or that a union had "slept on its rights," by accepting undertakings to subsequently bargain in good faith, ${ }^{65}$ by limiting locus standi to the Company and the Union involved, ${ }^{\circ 6}$ and, indeed, by questionable findings of good faith. ${ }^{67}$ In short, consents to prosecute have provided substantial procedural and psychological barriers to an applicant.

56 This problem is discussed at length in Cox, ante, $\mathrm{n} .21$, at 1414.

57 Id., at 1436.

58 See Can., s. 43 ; Man., s. 40; s. 41; Nfd., s. 44; and N.S., s. 43.

50 See Alta., s. $72(7,8)$, B.C., s. 60 ; and Que., s. 42.

60 Re H.E.P.C. Ont (1964), OLRB Mon. Rep. Apr. 64, at and Re Byers Const. (1957) 2 CLS 76-572, CCH par. 16, 088 (Ont.). Thus, as was pointed out in Re Wright Assemblies (1961), 2 CLS 76-786, CCH par. 16, 215 (Ont.), "The Board is not empowered nor called upon to make any decision with respect to the merits of the whole case... [and] it is not incumbent upon the applicant in applying for consent to prosecute to advance his whole case before the Board." Other Boards in Canada simply regard as their function "to sift out the merely frivolous and vexatious cases and leave it to a Court of competent jurisdiction to deal with the merits": Re New Method Launderers (1953), CLS 60-1034 (Man.); and also see Re Medjucks Furniture (1957), par. 16, 062 (N.B.).

01 The wide discretion exercised is best shown in Re Hamilton Const. Assn., OLRB Mon. Rep. Mar. 61, at 452; Re Savage Shoes (1953), 2 CLS 76-401; CCH par. 17, 060 (Ont.); and Re Western Freight Lines, OLRB Mon. Rep. Aug. 64, at 180.

62 Re Superior Box Co., ante, n. 31; Re Radio Oil Refineries, ante, n. 37.

63 Re McPherson Warehousing Co., ante n. 40.

64 See Re Hanover Kitchens, OLRB Mon. Rep. Jan. 63, at 438; Re Mattagami Const. Co., OLRB Mon. Rep. Mar. 65, at 648; and Re American Standard Products, OLRB Mon. Rep. Feb. 65, at 590 .

65 Re Twin City Laundry, ante, n. 30.

66 Re American-Standard Products, ante, n. 64.

67 Re Twin City Laundry, ante, n. 30. 
The criminal nature of the proceedings has also had the effect of precluding the parties from seeking this relief. This paucity of complaints was shown by Professor Logan when he provided statistics to show that between 1944 and 1954 the Ontario Board only dealt with two failure to bargain cases ${ }^{68}$ and between 1948 and 1952 the Dominion Board six, only one of the latter being successful. ${ }^{69}$ The explanation for this also comes from Professor Logan, who says: "To "The reason for this, at at time when negotiations have failed so frequently and long delays have been so common, is reported to be the long-run psychological effect. Better to use conciliation and trust to developing good relations than to hail an employer or a union into court." This statement seems clearly right: criminal remedies are incompatible with the development of mutual accommodation reguired by our legislation.

A more palatable method of obtaining the presumed end of such process would be a national policy of enforcement by the Boards themselves of breaches of the obligation in good faith. ${ }^{71}$ Such a method removes the taint of Old Bailey while still permitting the exact scope of the requirements of such provisions to be settled by Boards familiar with the problems. Unfortunately, in Ontario at least, such a proposal by the Select Committee on Labour Law was not adopted at the last revision of the Acts in 1960.i2 Further, it seems highly unlikely that this approach will be adopted.

\section{III}

In result the replacement of emphasis on compulsory conciliaton by a greater stress on "good faith bargaining" does not seem to be the solution for problems in the field of negotiation of collective agreements. The concept of "good faith" would seem to be incompatible with the freedom of the individual company or union to enter, or to refuse to enter into contractual relationships on terms of their own choice. Even accepting that this freedom is not complete, within the legitimate area of agreement possible under our laws the parties should be free to resolve their own differences as best they can. In short, the function of collective bargaining legislation is to balance, in a very rough way, the economic power of the parties; ${ }^{78}$ how his power is used depends on the capabilities and inclinations of the parties involved.

In fact, "good faith" is not a part of the bargaining process and, indeed, seems impossible of attainment under the conditions of the existing economic system. Unions and compauies are bodies actuated by self-interest and their conduct reflects this fact. Thus, to impose the concept of good faith into their mutual activities is to introduce a fiction. Unfortunately, it is a harmful fiction because it distracts the parties from the central purpose of working out an agreement and stimulates the negotiators to build up a case for an unfair practice ${ }^{74}$ or to go through the

68 See Logan, ante, n. 10 , at 62.

$68 \mathrm{Id}$., at $49-50$.

70 Ibtd.

71 This proposal has also been made by Professor Woods: id., at 62.

72 Macleod, $A$ Collation and Commentary on Briefs Submitted to the Select Committee on Labour Relations 40 (1958).

73 See Bromke, ante, n. 1, c. 1, esp. 16.

74 As stated by Cox, ante, n. 21, at 1440: "Hammering out a labor agreement requires all the negotlators' skill and attention. To divert them from the main task by putting a value on bullding up or defeating an unfair labor-practice case diminishes the likelihood that negotlations will be successful." 
charade of adhering to the objective tests of good faith then prevailing. Indeed the threat of criminal prosecution may even have the effect of forcing a party into reluctant submission on a particular point, which he could have avoided in a clash of economic power. All that should be required is that the two parties meet together and listen to the other side untrammelled by rules which obscure the reality of the situation. ${ }^{75}$ At this point, a decision could be reached on the actual interests involved, thus sweeping aside the continuing fictions which later occur in collective agreement interpretation that they should receive a liberal interpretation as they are products of "good faith."

75 For other views that the concept of good falth has outlived its usefulness, see Petro, The Labor Policy of a Free Society, 214-17, 254-56 (1957) and Gregory, ante. n. 54, at 414. For opposite views, see O'Neill, ante, n. 66 at 214, and Dooley, Union's Duty to Bargain Collectively with the Employer (1947), 8 Lab. L. J. 249.

i6 See, e.8., per McNiven, J.A., in Marshall-Wells v. Retail, Wholesale \& Dept. Store Union, Loc. 454, [1955]' 4 D.L.R. 591, 599 (Sask. C.A.): "Good faith is basic to the purpose of the Trade Union Act-it is basic to everything done or advanced in the course of negotiations by elther party-it is basic to the Act itself and it necessarily follows that good faith is an essential element to any concluded agreement." 